\title{
Invasive vertebrate species in Chile and their control and monitoring by governmental agencies
}

\author{
Especies de vertebrados invasores en Chile y su control y monitoreo \\ por agencias gubernamentales
}

\section{J. AGUSTÍN IRIARTE, GABRIEL A. LOBOS \& FABIÁN M. JAKSIC}

\author{
Center for Advanced Studies in Ecology \& Biodiversity, Pontificia Universidad Católica de Chile, \\ Casilla 114-D, Santiago, Chile \\ Corresponding author: e-mail: fjaksic@bio.puc.cl
}

\begin{abstract}
We provide an overview of the current status of vertebrate invasive species throughout Chile, updating information on terrestrial exotics and reporting for the first time the situation of exotic freshwater fishes. In addition, we document the legislation and programs that the Chilean government has implemented to limit the entry of exotics to the country or minimize their impact on native wild flora and fauna and on natural ecosystems. We document what is known about the introduction of 26 exotic fish species to continental waters of the country, discussing the distribution and putative effects of those 11 species that may be considered invasive. From a previous list of 24 terrestrial vertebrate invaders, we withdraw the Argentine tortoise (Chelonoidis chilensis), reindeer (Rangifer tarandus) and mouflon (Ovis ammon) because there are no data on their subsistence in the wild. On the other hand, we add three new species: red-eared freshwater turtle (Trachemys scripta), monk parakeet (Myiopsitta monachus), and red-crested cardinal (Paroaria coronata), thus keeping the total number of terrestrial invaders unchanged at 24 species. The chief agency in charge of existing laws and regulations regarding the import of exotic freshwater species is the National Fisheries Service (SERNAPESCA, in Spanish), a dependency of the Ministry of Economy. The main agency in charge of enforcing existing laws and regulations regarding the import of exotic terrestrial species to Chile is the Agriculture and Livestock Service (SAG, in Spanish), a dependency of the Ministry of Agriculture. Currently, SAG is not only controlling major border passes, seaports and airports, but also is funding studies to monitor and control already existing invaders. In addition, the Chilean Forest Service (CONAF, in Spanish) is also concerned about invasive species, but only if they enter national parks and reserves within the National System of Protected Wildlife Areas (SNASPE, in Spanish).
\end{abstract}

Key words: exotic fishes, exotic amphibians, exotic reptiles, exotic birds, exotic mammals.

\section{RESUMEN}

Entregamos una revisión del estado actual de las especies de vertebrados invasores en Chile, actualizando información sobre las especies exóticas terrestres y documentando la situación de las especies exóticas de peces dulceacuícolas. Además, revisamos la legislación pertinente y los programas que el gobierno chileno ha implementado para limitar la entrada de especies exóticas al país o para minimizar su impacto sobre la flora y fauna nativas y los ecosistemas naturales. Documentamos lo que se conoce sobre la introducción de 26 especies exóticas de peces a las aguas continentales de Chile, discutiendo la distribución y efectos putativos de 11 especies que pueden considerarse invasivas. De la lista previa de 24 especies invasoras de vertebrados terrestres, nosotros retiramos la tortuga argentina (Chelonoidis chilensis), el reno (Rangifer tarandus) y el muflón (Ovis ammon), porque no hay evidencias de que hayan logrado asilvestrarse. Por otra parte, agregamos la tortuga dulceacuícola de orejas rojas (Trachemys scripta), la cotorra argentina (Myiopsitta monachus) y el cardenal de cresta roja (Paraoria coronata), manteniéndose así el total de invasoras constante en 24 especies. La principal agencia a cargo de implementar las leyes y regulaciones existentes con respecto a la importación de especies exóticas de peces es el Servicio Nacional de Pesca (SERNAPESCA), una dependencia del Ministerio de Economía. La principal agencia a cargo de aplicar las leyes y regulaciones vigentes sobre la importación de especies exóticas terrestres a Chile es el Servicio Agrícola y Ganadero (SAG), una dependencia del Ministerio de Agricultura. Actualmente, el SAG no solo controla los pasos fronterizos, puertos y aeropuertos de Chile, sino 
también financia estudios para monitorear y controlar los invasores ya presentes en el país. Además, la Corporación Nacional Forestal (CONAF) también se involucra con especies invasoras, pero solo si ellas entran al Sistema Nacional de Áreas Silvestres Protegidas del Estado (SNASPE).

Palabras clave: peces exóticos, anfibios exóticos, reptiles exóticos, aves exóticas, mamíferos exóticos.

\section{INTRODUCTION}

The Convention on Biological Diversity (convened in Rio de Janeiro, Brazil, 1992) recognized invasive species as one of the main threats to biodiversity (together with climate change and habitat loss), owing to their disruptive effects for native species in communities, for vital ecosystems processes such as nutrient cycling and water depuration, and for the delivery of ecosystem goods to humanity. In 2002, the Sixth Conference of the Parties to the Convention met in Cape Town, South Africa, and agreed on 15 principles aimed at developing strategies to retard the spread and minimize the impact of invasive species, and at taking measures such as research, monitoring, border control, mitigation, and eradication. All of these actions require an intensive use of public funds and institutions, in alliance with researchers at major universities, institutes and centers.

The first step toward controlling exotic invasive species is to identify them, determine their geographic origin, their pathways of invasion, their interactions with native species, and the rippling effects they have on communities and ecosystems. Except for developed countries, knowledge of invasive species and their effects is very limited in most of the world. Chile is no exception to this trend, which has only slightly reversed with the recent publications of Fuentes-Contreras et al. (1997) on aphids, Jaksic (1998) on terrestrial vertebrates, Valdovinos-Zarges (1999) on mollusks, and Arroyo et al. (2000) on vascular plants. Jaksic (1998) reported that only 24 terrestrial vertebrate species $(3.9 \%$ of the ca. 610 native species) had invaded Chile, of which humans introduced 20, while the remainder entered the country on their own. Despite their small number, some of these invader species have already left profound impressions on communities and landscapes, for instance, rabbits in central Chile (Jaksic \& Fuentes 1991) and American beaver in southernmost Chile (Jaksic et al. 2002).
Jaksic (1998) did not include freshwater fishes in his report, for which the situation may be more dramatic, given the existence of only 44 native species in all of Chile. Indeed, Gajardo \& Laikre (2003) called attention to the fact that the Chilean export boom, which has placed it as the second world exporter of salmon (Atlantic and coho salmon together with rainbow trout), is based on the aquaculture of exotic species, which in addition are invasive (Wood 1997, Soto et al. 2001, Pérez et al. 2004). Perhaps not amazingly, few Chilean researchers are inclined to labeling these species as invaders that must be eradicated from natural ecosystems, as mandated by the Convention on Biological Diversity (Gajardo \& Laikre 2003, Camus 2005). This, in spite of the fact that their negative ecological effects in communities and ecosystems seem to be out of question (Huaquín \& Manríquez 1986', VegaAguayo et al. $1986^{2}$, Soto et al. 2001, Gajardo \& Laikre 2003, McDowall et al. 2003). A problem, though, is that they have already invaded most of the suitable habitats, and so there is little hope to reconstruct the original food webs, and thus to scientifically ascertain the impact of these invaders (Pascual et al. 2002).

Here, we attempt a three-pronged approach to evaluating the status of invaders in Chile: (1) We update information on terrestrial vertebrate invaders, withdrawing three species previously labeled as invaders, and adding three new species to the account provided by Jaksic (1998). (2) We now include a tally of introduced freshwater fishes, describing their geographic origin, date, place and motivation

\footnotetext{
${ }^{1}$ HUAQUÍN L \& A MANRÍQUEZ (1986) Problemática y perspectiva de los peces nativos de aguas continentales chilenas (Resumen). Centro de Investigación y Planificación del Medio Ambiente, segundo encuentro científico sobre el medio ambiente, Talca, Chile.

2 VEGA-AGUAYO R, I VALDEBITO \& R PALMA (1986) Trucha arco iris: su impacto sobre el ecosistema (Resumen). Centro de Investigación y Planificación del Medio Ambiente, segundo encuentro científico sobre el medio ambiente, Talca, Chile.
} 
for their introduction, the current extent of their distribution in Chile, and the putative effects they are having among native fauna and ecosystems. (3) Finally, we describe the legal and administrative context under which exotic species, both terrestrial and aquatic, are dealt with by the government of the country.

\section{Study region and nomenclature}

The South American country of Chile is long and narrow, ca. 4,200 km long by 177 wide on average. It is oriented essentially along a straight north-south axis, and encompasses a length that in North America is equivalent to the Pacific board from the tip of Baja California (Mexico) to Canada and southern Alaska (USA). Chile is divided into 13 administrative regions, numbered sequentially from north to south with roman numerals (Fig. 1). All of them (except for the landlocked Metropolitan Region, encapsulated between regions $\mathrm{V}$ and VI) encompass from the Andean mountains to the Pacific Ocean. Regions I to II span all of the Atacama desert in northernmost Chile, a stretch of the country known as "Big North." Regions III and IV are a semi-desert in northern Chile, which is called "Little North." Regions V to VIII stretch over central Chile, an area previously dominated by evergreen scrublands, but now occupied by cities amid agricultural fields and forestry plantations. Regions IX and X were dominated by broad-leaved forests before going up in smoke to open the land for cattle raising and agriculture. Because of the presence of large glacial lakes here, this part of the country is known as "Lake District." Regions XI and XII in the southernmost part of the country are partly dominated by Nothofagus forests and by steppe, and make up "Chilean Patagonia."

Because of the narrowness and steep incline of the country from the tall Andean Ranges west to the Pacific Ocean, all rivers run east to west, straight and speedy. In addition, the largest lakes are located essentially within the confines of the IX Region, named "Araucanian Region" and of the X Region, aptly named "Lake Region." There are also substantial lakes in the Patagonian regions XI and XII. For scientific nomenclature of species, we follow Simonetti et al. (1995).

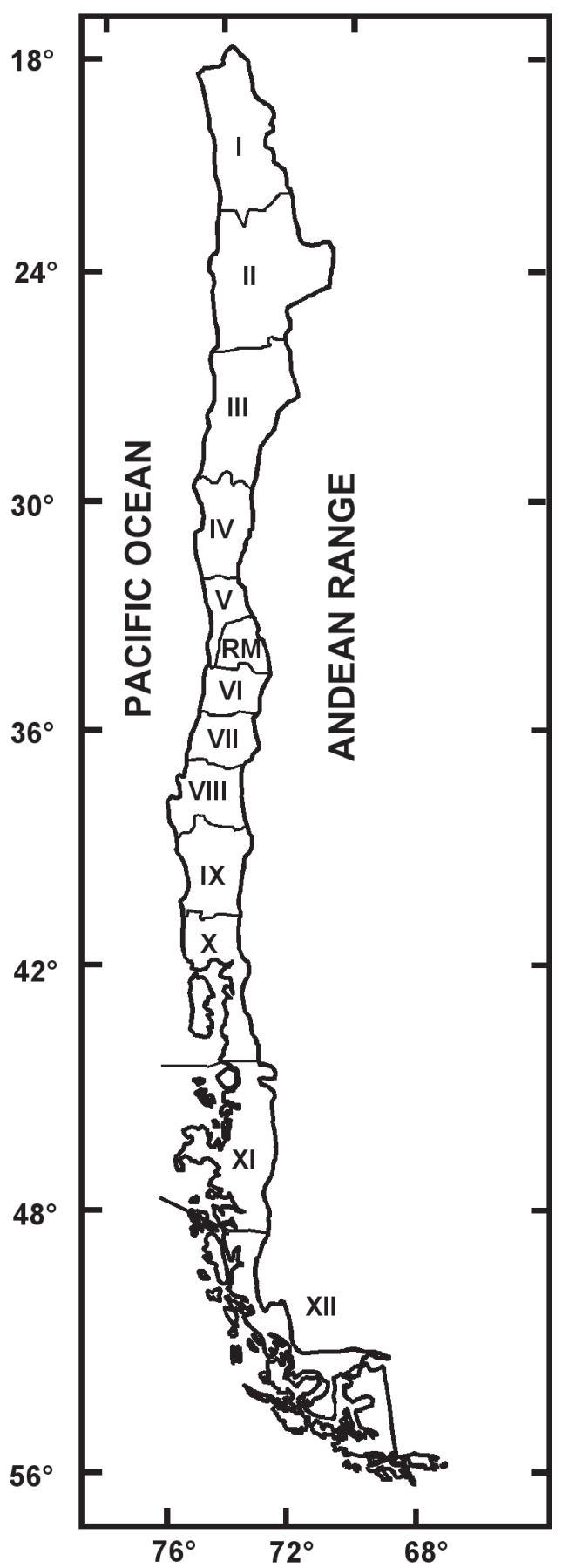

Fig. 1: Map of Chile with its 13 administrative regions (from I to XII plus the Metropolitan Region), latitudes and longitudes, neighboring countries, and major geographic features. The physiognomy of the country is described in the study region and nomenclature section.

Mapa de Chile con sus 13 Regiones administrativas (desde la I a la XII, además de la Región Metropolitana), latitudes y longitudes, países vecinos, y atributos geográficos mayores. La fisonomía del país se describe en la sección "Study region and nomenclature". 
UPDATES ON THE EXOTIC VERTEBRATE FAUNA OF CHILE

\section{Freshwater fishes}

Freshwater fish were not considered in Jaksic's (1998) account of exotic invasive species in Chile. The native freshwater ichthyofauna of Chile is represented by 44 species (Campos 1973, Pequeño 1989, 1995, CONAF 1993, Dyer 2002), of little commercial interest (Huaquín \& Manríquez 1986), to which 26 exotic species should be added (De Buen 1959, Campos 1970, Duarte et al. 1970, Arratia 1978, 1981, Fundación Chile 1990, Brito 2002, Dyer 2002, see Table 1). Only nine or eleven (if one includes Acipenser transmontanus and Ameiurus nebulosus) of these exotic species may be considered truly invasive, on account of their naturalization in the wild and their spread over the country (Table 2).

The account of the exotic fish introductions to Chile is fragmentary. The chief motive for their introduction to the country has been their use in aquaculture, with sports fishing, ornamental use, and use as biological control agents lagging far behind (Table 1). In 1890, eggs of Salmo sp. were imported to a private facility in northern Chile, but this introduction did not involve their release to the wild. In 1903, the Chilean government set up a program to introduce six salmonid species to freshwater lakes and lagoons. The first 400,000 eggs came from Hamburg (Germany) and arrived to Chile by train via Argentina. The eggs were hatched in the first hatchery built in Chile (Blanco River, Region V). The species involved were Atlantic salmon (Salmo salar), coho salmon (Oncorhynchus kisutch), chinook (Oncorhynchus tschawytscha), rainbow trout (Oncorhynchus mykiss), brown trout (Salmo trutta fario), and brook trout (Salvelinus fontinalis). Some of these salmonid species were released to several rivers from the Aconcagua River (Region V) to the Tolten River (Region IX), and over a century invaded the whole country.

Introduced salmonids seem to have affected the species composition, trophic interactions, and nutrient dynamics of most of the freshwater systems in Chile (Arenas 1978, Ladermann \&
Pichot 1984, Huaquín \& Manríquez 1986, Vega-Aguayo et al. 1986, Wood 1997, Soto et al. 2001). Perhaps for these reasons, all of the 44 native freshwater species are considered as threatened (CONAF 1993). Nevertheless, hard data are difficult to come by (Table 2).

\section{Amphibians}

The first mention to an exotic amphibian in Chile was made by Donoso-Barros (1970), referring to the presence of the European triton Triturus cristatus in the laboratories of the School of Medicine of the University of Chile in Santiago. This species reproduced extensively in large tanks kept at this school, leading Donoso-Barros (1970) to fear their spread to the wild. Nevertheless, the school building burnt together with the tanks, and the triton disappeared. Thus, only one exotic frog species has invaded Chile up to now. Jaksic (1998) reported that the African clawed frog (Xenopus laevis) was introduced in 1973 to Santiago (Metropolitan Region) and that it had spread west to Region V and south to Region VI. Lobos \& Jaksic (2004) reported its presence further north, in Region IV. During the late 1980's a batch of these frogs was sent to the University of Concepción (Region VIII), where they were kept for laboratory experiments and demonstrations (Hermosilla 1994). They do not seem to have been released to the wild, but this needs confirmation (Lobos \& Measy 2002, Lobos \& Jaksic 2004). There are no hard data regarding the possible effects of the introduction of this species on native fauna, but biologists suspect a detrimental impact on native amphibians (Lobos \& Jaksic 2004). Still, dietary analyses of four populations of African clawed frogs in the Metropolitan Region failed to reveal consumption of native frogs or fishes (Lobos et al. 1999). Indeed, the only vertebrates found in the diet were juveniles and tadpoles of the same species, thus revealing cannibalism. In two different habitats of the Metropolitan Region, Lobos \& Measey (2002) estimated densities of 0.25 and 0.37 clawed frogs $\mathrm{m}^{-2}$, somewhat lower than those reported in California and Arizona (USA) and South Wales (United Kingdom). 


\section{TABLE 1}

The 26 species of exotic fishes introduced to freshwaters of Chile, in alphabetical order by scientific name

Las 26 especies de peces exóticos introducidos en aguas continentales de Chile, en orden alfabético por nombre científico

\begin{tabular}{|c|c|c|c|c|}
\hline Scientific (common) names & Origin & Motivation & When & Introduced to \\
\hline Acipenser baeri (baikal sturgeon) & Russia & Aquaculture & 1997 & Chacabuco (Region XI) \\
\hline Acipenser transmontanus (white sturgeon) & North America & Aquaculture & 1993 & $\begin{array}{l}\text { Maipo River } \\
\text { (Metropolitan Region) }\end{array}$ \\
\hline Ameiurus melas (black bullhead catfish) & North America & Aquaculture & Undated & Somewhere in central Chile \\
\hline Ameiurus nebulosus (bullhead catfish) & North America & Aquaculture & 1908 & Somewhere in central Chile \\
\hline Carassius auratus (gold fish) & $\begin{array}{l}\text { Central Asia, } \\
\text { China, Japan }\end{array}$ & Ornamental & 1856 & Somewhere in central Chile \\
\hline Cheirodon interruptus (Uruguay tetra) & $\begin{array}{l}\text { Argentina, Brazil, } \\
\text { Uruguay }\end{array}$ & Accidental & 1960 & Peñuelas Lake (Region V) \\
\hline Cichlasoma fecetum (chamaeleon cichlid) & $\begin{array}{l}\text { Argentina, Brazil, } \\
\text { Uruguay }\end{array}$ & Ornamental & 1940 & Peñuelas Lake (Region V) \\
\hline Cnesterodon decemmaculatus (mosquitofish) & Argentina & Ornamental & Undated & Valparaíso (Region V) \\
\hline Coregonus clupeaformis (common whitefish) & North America & Aquaculture & 1949 & Concepción (Region VIII) \\
\hline Ctenopharyngodon idella (grass carp) & China, Siberia & $\begin{array}{l}\text { Biological } \\
\text { control }\end{array}$ & 1995 & $\begin{array}{l}\text { San Pedro Lagoon (VIII), Paine } \\
\text { (Metropolitan R.) }\end{array}$ \\
\hline Cyprinus carpio (common carp) & Central Asia, & $\begin{array}{l}\text { Aquaculture } \\
\text { China, Japan }\end{array}$ & 1874 & Valdivia (Region X) \\
\hline Gambusia holbrooki (mosquitofish) & North America & $\begin{array}{l}\text { Biological } \\
\text { control }\end{array}$ & 1930 & Somewhere in northern Chile \\
\hline Ictalurus punctatus (channel catfish) & North America & Aquaculture & 1995 & Parral (Region VIII) \\
\hline Odonthestes bonariensis (Argentine silverside) & Argentina, Uruguay & Sportfishing & 1960 & Peñuelas Lake (Region V) \\
\hline Oncorhynchus gorbuscha (pink salmon) & $\begin{array}{l}\text { Arctic and } \\
\text { eastern Pacific }\end{array}$ & Aquaculture & 1981 & Simpson River (Region XI) \\
\hline Oncorhynchus keta (chum salmon) & $\begin{array}{l}\text { Japan, Korea, } \\
\text { North America }\end{array}$ & Aquaculture & 1972 & Simpson River (Region XI) \\
\hline Oncorhynchus kisutch (coho salmon) & North America & Aquaculture & 1930 & No data \\
\hline Oncorhynchus mykiss (rainbow trout) & North America & $\begin{array}{l}\text { Aquaculture, } \\
\text { Sport fishing }\end{array}$ & 1905 & Blanco River (Region V) \\
\hline Oncorhynchus nerka (red salmon) & North America & Aquaculture & 1930 & No data \\
\hline Oncorhynchus tschawytscha (chinook salmon) & North America & Aquaculture & 1924 & No data \\
\hline Salmo salar (Atlantic salmon) & $\begin{array}{l}\text { Canada, Finland, } \\
\text { Russia }\end{array}$ & Aquaculture & 1905 & Blanco River (Region V) \\
\hline Salmo trutta (brown trout) & Europe & $\begin{array}{l}\text { Sport fishing, } \\
\text { Aquaculture }\end{array}$ & 1905 & Blanco River (Region V) \\
\hline Salvelinus fontinalis (Brook trout) & North America & Aquaculture & 1905 & Blanco River (Region V) \\
\hline Salvelinus namaycush (lake trout) & North America & Aquaculture & 1949 & Concepción (Region VIII) \\
\hline Tinca tinca (tench) & Europe & Aquaculture & 1927 & $\begin{array}{l}\text { Somewhere in central Chile and in } \\
\text { Region X }\end{array}$ \\
\hline
\end{tabular}


TABLE 2

Known geographical distribution of 11 invasive fishes in Chile, their putative effects, and type of evidence, in alphabetical order by scientific name

Distribución geográfica conocida de 11 especies de peces invasores en Chile, sus efectos putativos, y tipo de evidencia, en orden alfabético por nombre científico

\begin{tabular}{|c|c|c|c|}
\hline Scientific name & Geographical distribution & Putative effects & Evidence \\
\hline Acipenser transmontanus & Mouth of Maipo River (V Region) & Predation on, competition with native fishes & Brito (2002) \\
\hline Ameiurus nebulosus & $\begin{array}{l}\text { Rinconada de Maipú, Mapocho River } \\
\text { (Metropolitan Region) }\end{array}$ & Predation on native fishes & Anecdotal \\
\hline Carassius auratus & $\begin{array}{l}\text { Santiago (Metropolitan Region) } \\
\text { Concepción (VIII Region) }\end{array}$ & $\begin{array}{l}\text { Unspecified detrimental effects } \\
\text { on the environment }\end{array}$ & Anecdotalto \\
\hline Cheirodon interruptus & $\begin{array}{l}\text { Choapa River (IV Region) to Santiago } \\
\text { (Metropolitan Region) }\end{array}$ & None known & None \\
\hline Cichlasoma fecetum & $\begin{array}{l}\text { Pichidangui (IV Region) to Santiago } \\
\text { (Metropolitan Region) }\end{array}$ & Competition with native fishes & Anecdotal \\
\hline Cnesterodon decemmaculatus & Creeks of Regions V and Metropolitan & None known & None \\
\hline Cyprinus carpio & $\begin{array}{l}\text { La Serena (IV Region) to Puerto Montt } \\
\text { (X Region) }\end{array}$ & $\begin{array}{l}\text { Unspecified detrimental effects } \\
\text { on the environment }\end{array}$ & Anecdotal \\
\hline Gambusia holbrooki & $\begin{array}{l}\text { Loa River (II Region) to Valdivia River } \\
\text { (X Region) }\end{array}$ & Predation on native fishes & Anecdotal \\
\hline Odonthestes bonariensis & Regions V and VI & Competition, hybridization with native silverside & Anecdotal \\
\hline Oncorhynchus mykiss & $\begin{array}{l}\text { Loa River (II Region) to Tierra } \\
\text { del Fuego (XII Region) }\end{array}$ & $\begin{array}{l}\text { Predation on, competition with native fishes; } \\
\text { changes in nutrient cycling in lakes }\end{array}$ & $\begin{array}{l}\text { Arenas (1978), } \\
\text { Laderman \& } \\
\text { Pichot (1984), } \\
\text { Soto et al. } \\
(2001)\end{array}$ \\
\hline Salmo trutta & $\begin{array}{l}\text { Aconcagua River (V Region) to Tierra } \\
\text { del Fuego (XII Region) }\end{array}$ & Predation on, competition with native fishes & $\begin{array}{l}\text { Arratia (1978), } \\
\text { Laderman \& } \\
\text { Pichot (1984) }\end{array}$ \\
\hline
\end{tabular}

\section{Reptiles}

Jaksic (1998) mentioned only one introduced reptile as present in Chile, the Argentine tortoise (Chelonoidis chilensis). Since the 1600 's large numbers of this tortoise have been imported to Chile. According to Richard (1995), over 30,000 tortoises were exported each year from Argentina to Chile during the period 1980 to 1995 . The species is considered vulnerable throughout Argentina by the Federal government, and is considered extinct in those provinces nearest to Chile: Mendoza, San Juan, and San Luis. Although it is common to see the Argentine tortoise in Chilean pet shops, it does not breed in the wild because the climate is seemingly too cold (Richard 1995), and thus this species does not qualify as invasive. Therefore, here we withdraw the Argentine tortoise from the list of invader species present in Chile.

In contrast, a different reptile species must be incorporated to the previous list: the redeared freshwater turtle Trachemys scripta, a native of Florida (USA). It is currently massively commercialized in Chilean pet shops, where it behaves voraciously and may reach up to $1 \mathrm{~kg}$. Núñez et al. (2002) collected a feral specimen in El Toyo, on the upper third of the Maipo River, which borders Santiago city by the south. In its native habitat in Florida, USA, this turtle feeds on invertebrates, amphibian and fish larvae, and also on carrion. This is an invader to watch out. 


\section{Birds}

Eight species of exotic birds have more or less successfully invaded Chile. Seven of them were reported by Jaksic (1998), and their situation has not changed much since then. They are the cattle egret (Bubulcus ibis), muscovy duck (Cairina moschata), ring-necked pheasant (Phasianus colchicus), California quail (Calliplepa californica), rock pigeon (Columba livia), shiny cowbird (Molothrus bonariensis), and house sparrow (Passer domesticus).

The newest, and possibly most troublesome invasive bird is the monk parakeet (Myiopsitta monachus). This species was released by private citizens in 1972, on the eastern part of Santiago city. Since then, 15,000 monk parakeets have been legally imported from Argentina and Uruguay for the pet trade. An import ban for this species has been in effect in Chile since 1997. Monk parakeets have spread throughout central of Chile, with breeding groups present in medium and large cities of regions $\mathrm{V}$ and Metropolitan. In addition, sightings of monk parakeets have been made in Copiapó (Region III) and Puerto Montt (Region $\mathrm{X})$. In a preliminary survey conducted in Santiago city (Metropolitan Region), about 90 breeding sites have been identified (S. Silva \& E. Silva personal communication). A major negative impact of the monk parakeet in Chile is claimed to be damage to fruit and ornamental trees. In Argentina, monk parakeets have been reported to cause over US\$ 1 billion per year in crop damage, because of 2-15\% crop losses of mostly corn and sunflower, but the bird's reputation as an agricultural pest seems to be overstated (Bucher 1992, Spreyer \& Bucher 1998). Interestingly, feral colonies of monk parakeets have been present in the US for over 30 years and they have not shown the massive outbreaks or agricultural damages once predicted (Spreyer \& Bucher 1998).

In addition, a few breeding pairs of the redcrested cardinal (Paroaria coronata), a common pet species legally brought from Argentina, have been seen regularly in agricultural valleys near Arica and Iquique cities (Region I) in northernmost Chile (Araya $\&$ Bernal 1995). Because there are so few records of this species, it is still too early to predict whether it will become truly invasive, but surely it is a species to watch out.

\section{Mammals}

Among terrestrial mammals, the situation has not changed much since Jaksic's (1998) report. European rabbits (Oryctolagus cuniculus) and European hares (Lepus europaeus) are considered pests throughout Chile. But they are also highly lucrative wildlife commodities. Almost 55,000 tons of meat were exported from Argentina during a $4 \mathrm{yr}$ period in 1976-1979 (Mares \& Ojeda 1984, Jackson 1986). This represented over US\$ 90 million (25\% of the total income from wildlife products exported from Argentina during that period). Chile exported over four million pelts and skins of hares and rabbits during a 75 y period (19101984). This represented (by number) almost 73 $\%$ of all official Chilean wildlife exports in that period (Iriarte \& Jaksic 1986, Iriarte et al. 1997).

Two species of semi-aquatic rodents have invaded the Patagonian region shared by Argentina and Chile: the American beaver (Castor canadensis) and the muskrat (Ondatra zibethicus). Jaksic (1998) reported on their respective introductions, and Jaksic et al. (2002) provided an exhaustive account of their invasion. Thus, we will only mention here that the success of these two invaders is surprising because in both Chilean and Argentine Patagonia there is a native species with a similar macroniche, the South American nutria or coypu (Myocastor coypus). This latter species has been introduced to several countries of the Northern Hemisphere with remarkable success (where it is considered invasive), but it has not impeded the spread of beaver or muskrat in their own native land. Skewes \& Olave (1999) showed that American beaver in Region XII are seriously damaging over 5,400 ha of native southern beech forests (Nothofagus pumilio) by construction of dams and by direct consumption. Little is known about the effect of Muskrat on native fauna or flora (Jaksic 1998). Other invasive rodents present in Chile are the Norway rat (Rattus norvergicus), the black rat (Rattus rattus), and the house mouse (Mus musculus), all chiefly restricted to human dwellings. Nevertheless, the two species of Rattus have been captured in natural environments of central Chile (Simonetti 1983, Lobos et al. 2005). One invasive carnivore, the coatimundi (Nasua nasua), is held responsible for the decline of native endemic birds in Juan 
Fernández Archipelago, including Juan Fernández petrel (Pterodroma externa), Cook's petrel (Pterodroma cooki), Kermadec petrel (Pterodroma neglecta), pink-footed shearwater (Puffinus creatopus), and flesh-footed shearwater (Puffinus carneipes) (Araya \& Bernal 1995). Another invasive carnivore, the American mink (Mustela vison), is considered to be responsible for the decline of the South American river otter (Lontra provocax) and of the coypu (Myocastor coypus) in Argentina (Pagnoni et al. 1986) and in Chile (Ruiz et al. 1996), but data on the diet and habitat preferences of the two former species in Chile do not seem in line with this view (Medina 1997).

The history of introductions of ungulates in Chile was referred to in detail by Jaksic et al. (2002), and thus we will not elaborate further here. Wild boar (Sus scrofa) and red deer (Cervus elaphus) are among the most invasive ungulates, with fallow deer (Dama dama) being less invasive. Indeed, red deer is said to outcompete two native deer species, the huemul (Hippocamelus bisulcus) and the pudu (Pudu pudu) (Povilitis 1981, Eldridge 1983). In reference to the previous list by Jaksic (1998), we now withdraw reindeer (Rangifer tarandus) and mouflon (Ovis ammon) as invaders, because there are no data about their successful establishment in the wild. In contrast, feral goats (Capra hircus) in Juan Fernández Archipelago are doing well and continue to have a negative impact on the native vegetation and fauna there (Colwell 1989, Wester 1991, Bourne et al. 1992). As an example of the commercial success brought by some exotic ungulates, Argentina exported over $56,000 \mathrm{~kg}$ of meat of axis deer (Axis axis) and of antelope (Antilope cervicapra) from 1976 to 1979 (Ojeda \& Mares 1982, Mares \& Ojeda 1984).

\section{CONTROL AND MONITORING OF EXOTIC VERTEBRATES IN CHILE}

\section{Freshwater species}

Currently, the governmental control and study of freshwater exotic species resides in the Ministry of Economy, specifically in the Undersecretariat for Fisheries (SUBPESCA, in Spanish) and in the National Fisheries Service
(SERNAPESCA, in Spanish). SUBPESCA is in charge of setting up general regulations for the sustainable exploitation of marine fisheries and aquaculture activities. SERNAPESCA depends from SUBPESCA, and is in charge of applying the General Fisheries and Aquaculture Act (Law № 18,862 of 1989). It what concerns to species introductions, Articles 11 to 13 of the Act, regulate the import of exotic species. New imports are defined as those species currently not in the country, and require authorization from the Service, previous presentation of taxonomic identity, certification of origin, description of destination, means of transportation, and a sanitary report. These new imports are banned from being released to the sea, rivers, lakes or any other water body, and Article 136 of the Act provides for penalties, including fines and prison.

\section{Terrestrial species}

Currently, the chief governmental control and study of invasive species resides in the Ministry of Agriculture, specifically in the Agriculture and Livestock Service (SAG, in Spanish). Another branch of the same Ministry, the Forest Service (CONAF, in Spanish) is also concerned about invasive species, but only if they enter national parks and reserves within the National System of Protected Wildlife Areas (SNASPE, in Spanish).

The lion's share of the SAG's task rests in the Department for the Protection of Natural Resources (DEPROREN, in Spanish). SAG as a whole, has been developing a national program that includes legislation, research and control programs. The main aims are: (1) to ban the introduction of potentially invasive species into Chile, even if intended for captive facilities; (2) to prevent the escape of captive individuals; (3) to monitor exotic species populations; (4) to prevent the spread of exotic species to areas where they are not present; (5) to reduce the impact of invasive species on native ones and their habitats; (6) to promote public education on the impact of invasive species; (7) to assess the potential economic use of exotic species; (8) to set up agreements concerning invasive species with countries with which borders are shared (Argentina, Bolivia, and Perú).

Toward the achievement of the above goals, the following Chilean legal bodies are invoked 
and applied: (1) the Agricultural Protection Act; (2) the Livestock Protection Act; (3) the General Fisheries and Aquaculture Act; (4) the Protected Areas Act; (5) the Wildlife Act. Several of these laws are new, and some include specifically the regulation of species introductions. For instance, the Wildlife Act (Law № 19,473 of 1996) regulates the import and export of wildlife specimens, including eggs, or any other biological material capable of propagating in the wild. Therefore, a special permit is needed to import exotic species to Chile, and for their release to the wild. This law also bans the translocation of any native species outside its natural geographic distribution. The penalties for violations of this rule are a maximum of $3 \mathrm{y}$ in prison, and a fine of up US\$10,000.

Chilean law requires animal and plant quarantines and issues strong regulations governing importation. The government has recently appropriated a relatively large budget to improve control of exotics at international borders and facilities. Most measures are based on an assessment of the risk posed by exotic species and their potential pathways of entry. SAG personnel confiscate from 2,000 to 3,000 non-native animal specimens every year. The species most commonly confiscated are monkeys (squirrel monkey, common marmoset, capuchin monkey, howler monkey, spider monkey, woolly monkey), parrots (Amazon parrot, blue-yellow macao), passerine birds, flamingos, land turtles or tortoises, and snakes. In order to control the introduction of exotic species into Chilean territory, SAG personnel patrol more than 80 border passes, marine ports, and international airports. Through SAG, the Chilean government has established communications with Argentina about invasive species such as boar, beaver, rabbit and hare. During the last decade, SAG has attempted to reduce the impact of invasive species on natural habitats and on native species. Some of the SAG's sponsored programs being conducted in Chile are: (1) monitoring of monk parakeet breeding sites, regions III to X; (2) population control of European hare and rabbit, regions XI and XII; (3) population control of American beaver and muskrat in Tierra del Fuego Island, Region XII (see Skewes \& Olave 1999).

CONAF, on the other hand, has sponsored the following programs: (1) population control of wild boar in Vicente Pérez Rosales National Park, Region X; (2) dispersal control of mink, regions X and XI (see Ruiz et al. 1996); (3) potential of mink fur for use in handcrafts, Region XI; (4) recovery program for Juan Fernández Archipelago conducted jointly by CONAF and the government of The Netherlands. The principal objectives of this latter program are (see Cuevas \& Leersum 2001): (a) population reduction of introduced flora and fauna; (b) educational program for local inhabitants; (c) setting up of dispersal barriers for some invasive species; (d) use of live traps to remove invasive species; and (e) search for new established populations of invaders, in order to eradicate them.

\section{Crosscutting regulations}

The National Commission on the Environment (CONAMA, in Spanish), a dependency of the Ministry of the Presidency's General Secretariat came into existence by Law № 19,300 of 1994. Among CONAMA's duties is the coordination and supervision of the System of Environmental Impact Assessment, which under Article 6 of the Regulations of the Act, mandates that an environmental impact study be called for whenever a new non-indigenous species or flora or fauna, or a genetically modified organism, is introduced to the country. Toward this aim, CONAMA (2001) produced a manual for the prevention, management, and control of exotic species.

\section{International treaties}

In addition to the country's laws, through its Ministry of Foreign Affairs, Chile enforces international agreements such as the Convention on International Trade of Threatened Fauna and Flora (CITES) by Law-Decree № 873 of 1975, Convention on Migratory Species (Bonn) by Law-Decree № 868 of 1979, Convention on Wetlands (Ramsar) by Law-Decree № 3,485 of 1980, and Convention on Biodiversity (Río de Janeiro) by Supreme Decree № 1,963 of 1995, All of these conventions regulate the introduction and exchange of exotic species, one way or another. More specifically, the ChileArgentina Treaty on the Environment (Supreme Decree № 67 of 1992) specifically sets institutional coordination activities to control the 
introduction and spread of wild boar, American mink, American beaver, African clawed frog, and monk parakeet.

\section{CONCLUSIONS}

For a long time it was considered that, in comparison to neighboring countries, Chile was in a better position to fend off naturally expanding potential invaders on account of the formidable barriers posed by the Atacama desert by the north, the Pacific Ocean by the west and south, and the Andean ranges by the east. But current evidence indicates that $-a t$ least for terrestrial vertebrates- the Andean ranges constitute only a permeable barrier (Jaksic et al. 2002) and that the pet trade is favoring the arrival of many potential invaders (Micol \& Jouventin 2002). It also seems clear that when potential invaders have been introduced by human agency into Chile, they have quickly spread throughout the country, leaving behind a trail of suspected or demonstrated detrimental effects on native flora and fauna. Blame for introductions of exotics has been equally shared by private citizens (for instance, import of ungulates for trophy hunting) and by governmental programs (for instance, import of salmonids for fly fishing and aquaculture). The institutional response in Chile has been rather slow at the start, essentially because invaders were not considered a serious problem, and since then, because of short supply of funds. If not for funding, at least concern has improved in recent years, providing hope that the arrival and spread of new invaders will be halted when it is still possible. We recommend that the attitude of Chilean agencies facing the threat of potential invaders should be "if you don't know what exotics may do to your country, don't let them in!"

\section{ACKNOWLEDGMENTS}

Martha Groom, Kent H. Redford, Jim Sanderson, Ronald Sarno, David K. Spicer, Doris Soto, Laurie Wilkins and Charif Tala made comments on different drafts of this paper. The main part of this study was made as part of JAI's former duties in the Department of
Protection of Natural Resources of the Ministry of Agriculture of the Chilean Government. FMJ acknowledges the support of grant FONDAPFONDECYT 1501-0001 to the Center for Advanced Studies in Ecology \& Biodiversity.

\section{LITERATURE CITED}

ARAYA B \& M BERNAL (1995) Aves. In: Simonetti JA, MTK Arroyo, A Spotorno \& E Lozada (eds) Diversidad biológica de Chile: 350-360. Comisión Nacional de Investigación Científica y Tecnológica, Santiago, Chile.

ARENAS J (1978) Análisis de la alimentación de Salmo gairdnerii Richardson en el Lago Riñihue y Río San Pedro, Chile. Medio Ambiente (Chile) 3: 50-58.

ARRATIA G (1978) Comentarios sobre la introducción de peces exóticos en aguas continentales de Chile. Ciencias Forestales (Chile) 2: 21-30.

ARRATIA G (1981) Géneros de peces de aguas continentales de Chile. Museo Nacional de Historia Natural, Publicación Ocasional (Chile) 34: 3-108.

ARROYO MTK, C MARTICORENA, O MATTHEI \& L CAVIERES (2000) Plant invasions in Chile: present patterns and future predictions. In: Mooney HA \& RJ Hobbs (eds) Invasive species in a changing world: 385-421. Island Press, Washington, District of Columbia, USA.

BOURNE WRP, M DE L BROOKE, GS CLARK \& T STONE (1992) Wildlife conservation problems in the Juan Fernández Archipelago, Chile. Oryx 26: 43-51.

BUCHER EH (1992) Neotropical parrots as agricultural pests. In: Beissinger SR \& NFR Snyder (eds) New World parrots in crisis: solutions from conservation biology: 201-219. Smithsonian Institution Press, Washington, District of Columbia, USA.

BRITO JL (2002) Primer registro de Acipenser transmontanus Richardson, 1863 asilvestrado en la desembocadura del Río Maipo, San Antonio, Chile central. Museo Nacional de Historia Natural, Noticiario Mensual (Chile) 347: 9-11.

CAMPOS H (1970) Introducción de especies exóticas y su relación con los peces de agua dulce de Chile. Museo Nacional de Historia Natural, Noticiario Mensual (Chile) 162: 3-9.

CAMPOS H (1973) Lista de peces de aguas continentales de Chile. Museo Nacional de Historia Natural, Noticiario Mensual (Chile) 198/199: 3-14.

CAMUS PA (2005) Intoducción de especies exóticas en ambientes marinos chilenos: no solo exóticas, no siempre evidentes. Revista Chilena de Historia Natural 78: 155-159.

COLWELL RK (1989) Hummingbirds of the Juan Fernández Islands: natural history, evolution and population status. Ibis 131: 548-566.

CONAF (Corporación Nacional Forestal) (1993) Libro rojo de los vertebrados terrestres de Chile. Segunda edición. Corporación Nacional Forestal, Santiago, Chile. 65 pp.

CONAMA (Comisión Nacional del Medio Ambiente) (2001) Fortalecimiento del sector público para la prevención, manejo y control coordinado de especies exóticas. Aquambiente Limitada, Santiago, Chile. 138 pp.

CUEVAS JG \& G VAN LEERSUM (2001) Project "conservation, restoration, and development of the 
Juan Fernández islands, Chile". Revista Chilena de Historia Natural 74: 899-910.

DE BUEN F (1959) Los peces exóticos en las aguas dulces de Chile. Investigaciones Zoológicas (Chile) 5: 103-137.

DONOSO-BARROS R (1970) Catálogo herpetológico Chileno. Museo Nacional de Historia Natural, Boletín (Chile) 31: 49-124

DUARTE W, R FEITO, C JARA, C MORENO \& A ORELLANA (1971) Ictiofauna del sistema hidrográfico del Río Maipo. Museo Nacional de Historia Natural, Boletín (Chile) 32: 227-268.

DYER B (2000) Systematic review and biogeography of the freshwater fishes of Chile. Estudios Oceanológicos (Chile) 19: 77-98.

ELDRIDGE W (1983) Impacto ambiental, alimentación y conducta social del ciervo rojo y dama en el sur de Chile. Corporación Nacional Forestal, Boletín Técnico (Chile) 9: 1-53.

FUENTES-CONTRERAS E， R MUÑOZ \& HM NIEMEYER (1997) Diversidad de áfidos (Hemiptera: Aphidoidea) en Chile. Revista Chilena de Historia Natural 70: 531-542.

FUNDACIÓN CHILE (1990) El libro del salmón. Santiago: www.fundch.cl

GAJARDO G \& L LAIKRE (2003) Chilean aquaculture boom is based on exotic salmon resources: a conservation paradox. Conservation Biology 17: 1173-1174.

HERMOSILLA I (1994) Un sapo africano que se queda en Chile. Museo Regional de Historia Natural, Comunicaciones (Chile) 8: 75-78.

IRIARTE JA \& FM JAKSIC (1986) The fur trade in Chile: an overview of seventy-five years of export data (1910-1984). Biological Conservation 38: 243-253.

IRIARTE JA, P FEINSINGER \& FM JAKSIC (1997) Trends in wildlife use and trade in Chile. Biological Conservation 81: 9-20.

JACKSON JE (1986) The hare trade in Argentina. Traffic Buletin 7: 72 .

JAKSIC FM (1998) Vertebrate invaders and their ecological impacts in Chile. Biodiversity and Conservation 7: 1427-1445.

JAKSIC FM \& ER FUENTES (1991) Ecology of a successful invader: the European rabbit in central Chile. In: Groves RH \& F di Castri (eds) Biogeography of mediterranean invasions: 273-283. Cambridge University Press, Cambridge, United Kingdom.

JAKSIC FM, JA IRIARTE, JE JIMÉNEZ \& DR MARTÍNEZ (2002) Invaders without frontiers: cross-border invasions of exotic mammals. Biological Invasions 4: 157-173

LADERMANN JA \& L PICHOT (1984) Análisis de la alimentación natural de Salmo gairdnerii Richardson y Salmo trutta Linnaeus en La Laguna Trupan, Chile. Memorias de la Asociación Latinoamericana de Acuicultura 5: 615-618.

LOBOS G \& GJ MEASEY (2002) Invasive populations of Xenopus laevis (Daudin) in Chile. Herpetological Journal 12: 163-168.

LOBOS G \& FM JAKSIC (2004) The ongoing invasion of African clawed frogs (Xenopus laevis) in Chile: causes of concern. Biodiversity and Conservation 14: 429-439.

LOBOS G, P CATTAN \& M LÓPEZ (1999) Antecedentes de la ecología trófica del sapo africano Xenopus laevis en la zona central de Chile. Museo Nacional de Historia Natural, Boletín (Chile) 48: 7-18.

LOBOS G, M FERRES \& RE PALMA (2005) Presencia de los géneros invasores Mus y Rattus en área naturales de Chile: un riesgo ambiental y epidemiológico. Revista Chilena de Historia Natural 78: 113-124.

MARES MA \& RA OJEDA (1984) Faunal commercialization and conservation in South America. BioScience 34: 580-584

MCDOWALL RM (2003) Impacts of introduced salmonids on native galaxiids in New Zealand upland streams: a new look at an old problem. Transactions of the American Fisheries Society 132: 229-238.

MEDINA G (1997) A comparison of diet and distribution of southern river otter (Lutra provocax) and mink (Mustela vison) in southern Chile. Journal of Zoology (London) 242: 291-297.

MICOL T \& P JOUVENTIN (2002) Eradication of rats and rabbits from Saint Paul Island, French Southern Territories. In: Veitch CR \& MN Clout (eds) Turning the tide: the eradication of invasive species: 199-205. IUCN SSC Invasive Species Specialist Group, International Union for Conservation of Nature, Gland, Switzerland.

NÚÑEZ H, D PINCHEIRA-DONOSO \& C GARÍN (2002) Trachemys scripta elegans (Wied, 1838) (Testudinata: Emydidae), tortuga de orejas rojas, en el cajón del Maipo, Chile. Museo Nacional de Historia Natural, Noticiario Mensual (Chile) 350: 43-44.

OJEDA RA \& MA MARES (1982) Conservation of South American mammals: Argentina as a paradigm. In: Mares MA \& HH Genoways (eds) Mammalian biology in South America: 505-521. University of Pittsburgh Press, Linesville, Pennsylvania, USA.

PAGNONI GO, JL GARRIDO \& MR MARÍN (1986) Impacto económico y ambiental del visón, Mustela vison (Schreber, 1877) en el norte de la Patagonia. CENPAT-CONICET, Dirección de Fauna Silvestre, Provincia de Chubut, Argentina. 20 pp.

PASCUAL M, P MACCHI, J URBANSKI, F MARCOS, C RIVA-ROSSI, M NOVARA \& P DELL'ARCHIPRETTE (2002) Evaluating potential effects of exotic freshwater fish from incomplete presence-absence data. Biological Invasions 4: 102-413.

PEQUEÑO G (1989) Peces de Chile: lista sistemática revisada y comentada. Revista de Biología Marina (Chile) 24: 1-132

PEQUEÑO G (1995) Peces. In: Simonetti JA, MTK Arroyo, A Spotorno \& E Lozada (eds) Diversidad biológica de Chile: 302-313. Comisión Nacional de Investigación Científica y Tecnológica, Santiago, Chile.

PÉREZ JE, C MUNOZ, L HUAQUÍN \& M NIRCHIO (2004) Riesgos de la introducción de tilapias (Oreochormis sp.) (Perciformes: Cichlidae) en ecosistemas acuáticos de Chile. Revista Chilena de Historia Natural 77: 195-199.

POVILITIS A (1981) The huemul: an endangered species in Chile. Oryx 12: 215-219.

RICHARD A (1995) Tráfico de tortugas de tierra (Geochelone spp.) en Argentina. Ph. D. Thesis, Universidad de Buenos Aires, Buenos Aires, Argentina.

RUIZ J, R SCHLATTER \& D BUCHER (1996) Estudio de la situación del visón (Mustela vison, Schreber 1777) y su impacto sobre las comunidades autóctonas de la X Región, como aporte a la protección y recuperación de Áreas Silvestres Protegidas del Estado. Corporación Nacional Forestal, X Región, Puerto Montt, Chile. 54 pp. + 21 fotos.

SIMONETTI JA (1983) Occurrence of the black rat (Rattus rattus) in central Chile. Mammalia 47: 131-132. 
SIMONETTI JA, MTK ARROYO, A SPOTORNO \& E LOZADA (eds) (1995) Diversidad biológica de Chile. Comisión Nacional de Investigación Científica y Tecnológica, Santiago, Chile. xii +364 pp.

SKEWES O \& R OLAVE (1999) Investigación, aprovechamiento y control del castor en islas Tierra del Fuego y Navarino. Servicio Agrícola y Ganadero, XII Región, Punta Arenas, Chile. 185 pp. + apéndices.

SOTO D, F JARA \& C MORENO (2001) Escaped salmon in the inner seas, southern Chile: facing ecological and social conflicts. Ecological Applications 11: 1750-1762.

Associate Editor: Cristián Estades

Received June 11, 2004; accepted November 25, 2004
SPREYER MF \& EH BUCHER (1998) Monk parakeet (Myiopsitta monachus). Birds of North America 322: 1-23.

VALDOVINOS-ZARGES C (1999) Chilean mollusks biodiversity: taxonomic and distributional data base. Gayana Zoología (Chile) 63: 111-164.

WESTER L (1991) Invasions and extinctions on Másatierra (Juan Fernández Islands): a review of early historical evidence. Journal of Historical Geography 17: 18-34.

WOOD JD (1997) The distribution of feral salmonids in inland Chilean waters. Thesis, Institute of Aquaculture, University of Stirling, Stirling, Scotland, United Kingdom. 